\title{
Analisis Pengaruh Penerapan Perspektif Balanced Scorecard Terhadap Peningkatan Kinerja UMKM
}

\author{
Arasy Alimudin ${ }^{1}$ \\ Magister Manajemen, Fakultas Ekonomi dan Bisnis, Universitas Narotama \\ Email : arasy.alimudin@narotama.ac.id \\ Achmad Zakki Falani ${ }^{2}$ \\ Magister Manajemen, Fakultas Ekonomi dan Bisnis, Universitas Narotama \\ Email :achmad.zakki@narotama.ac.id \\ Sri Wiwoho Mudjanarko ${ }^{3}$ \\ Magister Teknik, Fakultas Teknik, Universitas Narotama \\ Email :sri.wiwoho@narotama.ac.id \\ Arthur Daniel Limantara ${ }^{4}$ \\ Teknik Sipil, Fakultas Teknik, Universitas Kadiri \\ Email :arthur.daniel@unik-kediri.ac.id
}

\begin{abstract}
The research conducted on UMKM commercial sector which aims to determine how much the contribution of the Balanced Scorecard (BSC) implementation by using four perspectives: financial, customer, internal business process and learning and growth. The concept Balanced Scorecard is deemed in accordance with the consideration that the concept is able to balance short-term plan with long-term plans, as well as to balance financial performance with the performance of non-financial. In addition, The benefits from this research is that companies have an appropriate business strategy and work program that can face of such change, enabling it to maintain and expand its business in the future in accordance with the vision and mission.By using these research techniques, application of the BSC through four perspectives can contribute significantly to the company's performance. This is indicate that UMKM oriented continuously on efforts to maintain customer satisfaction to earn the trust of the quality of the product followed by their support productive and committed employees who will be able to deliver products / services efficiently, consistent and timely with using technology information that have an impact on the organization's ability to generate adequate financial returns.
\end{abstract}

Key Word: Balanced Scorecard, UMKM performance, Information Technology.

ABSTRAK
Penelitian yang dilakukan pada sektor komersial UMKM yang bertujuan untuk
mengetahui seberapa besar kontribusi penerapan Balanced Scorecard (BSC) dengan
menggunakan empat perspektif: keuangan, pelanggan, proses bisnis internal dan
pembelajaran dan pertumbuhan. Konsep Balanced Scorecard dianggap sesuai dengan
pertimbangan bahwa konsep ini mampu menyeimbangkan rencana jangka pendek dengan
rencana jangka panjang, serta menyeimbangkan kinerja keuangan dengan kinerja non-
keuangan. Selain itu, Manfaat dari penelitian ini adalah bahwa perusahaan memiliki
strategi bisnis yang tepat dan program kerja yang dapat menghadapi perubahan tersebut,
memungkinkan untuk mempertahankan dan memperluas bisnisnya di masa depan sesuai
dengan visi dan misi. Dengan menggunakan teknik penelitian ini , penerapan BSC
melalui empat perspektif dapat memberikan kontribusi signifikan terhadap kinerja 
perusahaan. Hal ini menunjukkan bahwa UMKM berorientasi terus menerus pada upaya mempertahankan kepuasan pelanggan untuk mendapatkan kepercayaan dari kualitas produk diikuti dengan dukungan mereka yang produktif dan berkomitmen karyawan yang akan mampu memberikan produk / jasa secara efisien, konsisten dan tepat waktu dengan menggunakan teknologi informasi yang berdampak pada kemampuan organisasi untuk menghasilkan pengembalian keuangan yang memadai.

Kata Kunci: Balanced Scorecard, Kinerja UMKM performance, Teknologi Informasi.

\section{PENDAHULUAN}

Kota Surabaya adalah ibukota provinsi Jawa Timur dengan jargon sebagai kota jasa dan perdagangan memiliki tingkat pertumbuhan sektor perdagangan sebesar $18.56 \%$. Di Kota Surabaya banyak berdiri pusat perdagangan dengan konsep pusat perbelanjaan yang bangunannya tinggi dan di dalamnya tersedia fasilitas rekreasi dan memakan area yang luas sudah tersebar dibeberapa kawasan. Bahkan di pusat kotanya sendiri, pusat perdagangan yang ada sudah memiliki karakter yang kuat sebagai sebuah kota dengan fasilitas perdagangan lengkap dan modern yang sedikit banyak mempengaruhi pedagangpedagang kecil dan pasar tradisional dari segi pendapatan. Begitu pula kehadiran minimarket-minimarket dengan konsep waralaba di kampung-kampung dan di setiap kantong permukiman, perlu diatur lokasinya agar tidak merugikan toko-toko ritel atau toko toko kecil lainnya yang tidak didukung oleh permodalan yang kuat.

Berdasarkan data BPS Jawa Timur jumlah minimarket di Jawa Timur pada tahun 2011 sebanyak 1448 mini market dan pada tahun 2014 bertambah menjadi 2304,dimana pertumbuhannya dari 2011-2014 sebesar 59\%.sedangkan toko kelontong yang banyak dimiliki oleh usaha mikro dan kecil pada tahun 2011 sebanyak 8387 dan pada tahun 2014 menjadi 8393, dimana hanya tumbuh sebesar 0.7\%.Kelemahan UMKM di Indonesia khususnya di Surabaya adalah pada aspek daya saing, baik daya saing harga maupun differensiasi, hal ini disebabkan latar belakang UMKM di Surabaya masih mengandalkan manajemen keluarga dalam pengembangan bisnis modelnya. Kondisi inilah yang menyebabkan pola pengelolaan UMKM masih sangat tradisional dan mengandalkan hubungan kekerabatan. Dan ini akan menjadi kelemahan utama UMKM dalam menghadapi Masyarakat Ekonomi ASEAN 2015,karena ASEAN akan menjadi pasar tunggal yang didukung oleh kebebasan aliran barang dan jasa,investasi,modal,tenaga kerja terampil.

Untuk menjadi UMKM yang kompeten,maka harus diubah pola pengembangan UMKM dari tradisional ke professional(melengkapi dengan aspek legal dan 
memanfaatkan teknologi),dari mengandalkan evaluasi kinerja secara konvensonal, diubah menjadi penilaian kinerja berbasis Teknologi Informasi. Sehingga data kinerja UMKM dapat dihimpun dalam sebuah wadah untuk menciptakan sinergi dan compact Advantage. Untuk itu usaha kecil sektor perdagangan dituntut untuk dapat mengambil strategi yang tepat didasarkan kepada analisis kinerja usaha mereka.Dan Analisis Prespektif Balanced Scorecard bagi UMKM akan membantu UMKM sektor perdagangan dalam mengukur kinerjanya dan memberikan kemudahan pada pemetaan kinerjanya, Dimana UMKM sektor perdagangan akan mudah menggunakanya walaupun tidak memiliki latar belakang manajerial dengan baik.

Balanced Scorecard sebagai alat ukur berbasis strategis, seperti perspektif keuangan, perspektif pelanggan, perspektif internal bisnis proses,dan perspektif Pembelajaran dan Pertumbuhan. Keunggulan penerapan Balanced Scorecard adalah untuk dapat memberikan ukuran yang dapat dijadikan sebagai dasar dalam perbaikan strategis. Metode Balanced Scorecard akan dapat menghasilkan sebuah produk sistem informasi penilaian kinerja UMKM yang efektif untuk menentukan kebijakan strategi pengembangan UMKM sektor perdagangan di Surabaya

\section{TINJAUAN PUSTAKA}

Berkembangnya sektor informal merupakan fenomena umum yang biasa terjadi di beberapa wilayah perkotaan khususnya di Surabaya. Tumbuh suburnya sektor informal pada dasarnya merupakan salah satu bentuk respon migran dan masyarakat miskin kota terhadap pembangunan antar daerah yang tidak merata, urbanisasi, meluasnya tingkat pengangguran dan merebaknya tekanan kemiskinan (tjiptoherijanto, 1989) artinya kehadiran dan perkembangan sektor informal di berbagai kota besar bukan didorong oleh faktor internal dalam diri mereka sendiri, tetapi lebih merupakan akibat dari terjadinya bias urban dalam pembangunan (manning dan effendi,1985). Selain itu, daya tahan, kelangsungan (sustainablility) dan fleksibilitas unit usaha informal khususnya PKL justru terletak pada dimensi informalitas dan fleksibiltas, sehingga unit usaha informal ini lebih cepat tumbuh banyak seiring dengan perkembangan kota, jumlah penduduk dan daya beli masyarakat kota Surabaya. Untuk itu diperlukan sebuah pengukuran kinerja UMKM yang tepat dan cepat sehingga pemerintah khususnya Dinas Koperasi dan UMKM Kota 
Surabaya dapat mengambil kebijakan yang tepat untuk meningkatkan kinerja UMKM sektor perdagangan Kota Surabaya.

Pengertian kinerja menurut Payaman Simanjuntak (2005) yang mengemukakan kinerja adalah tingkat pencapaian hasil atas pelaksanaan tugas tertentu. Kinerja perusahaan adalah tingkat pencapaian hasil dalam rangka mewujudkan tujuan perusahaan. Menurut Islami A.C., et al (2017) di dalam mengukur kinerja UMKM di Surabaya dibutuhkan sebuah alat ukur yang tepat dimana tidak hanya didasarkan pada alat ukur finansial saja tetapi juga alat ukur non finansial disesuaikan dengan tujuan dari sebuah pengukuran. Dan balanced scorecard merupakan suatu pengukuran kinerja dan sistem manajemen yang memandang perusahaan dari empat perspektif, yaitu perspektif keuangan, pelanggan, proses bisnis internal serta pembelajaran dan pertumbuhan untuk memperbaiki keputusan strategis dalam mencapai tujuan perusahaan serta memberikan pemahaman kepada manajer atau UMKM terhadap performance bisnis(Kaplan \& Norton, 1996).

BSC merupakan sebuah sistem instrumentasi bagi pelaku usaha untuk mengendalikan organisasi perusahaan guna mentranslasikan visi dan misi perusahaan ke dalam bentuk kerangka pengukuran strategis terhadap sekumpulan parameter didalam masing-masing perspektif yang komprehensif, sehingga dapat meningkatkan kemampuan kerja perusahaan guna menciptakan daya saing yang berkelanjutan (sustainable competitive advantage) dalam kondisi persaingan yang kompentitif dewasa ini. Berdasarkan hal tersebut UMKM perlu menerapkan sebuah model pengukuran kinerja yang komprehensif berdasarkan Balanced Scorecard serta memerlukan pembuktian seberapa besar kontribusi penerapan BSC tersebut terhadap kinerja perusahaan.

Keempat perspektif dalam balanced scorecard merupakan satu kesatuan yang tidak dapat dipisahkan, saling melengkapi sebagai indikator pengukuran kinerja dan memiliki hubungan sebab akibat. Perspektif keuangan merupakan muara atau hasil akhir dari tiga perspektif lainnya. Untuk mengukur kinerja finansial UMKM dilakukan dengan melihat indikator keuangan meliputi tingkat keuntungan, tingkat penjualan, dan efisiensi biaya(Bank Indonesia., 2016; Sasono, Alimudin, Kamisutara, \& Inayati, 2015). Perspektif pelanggan dikembangkan berdasarkan hasil penelitian sebelumnya meliputi : kemampuan untuk mendapatkan kepercayaan pelanggan, hubungan yang baik dengan pelanggan baik internal maupun eksternal, kemampuan mempertahankan pelanggan 
lama dan pelayanan kepada pelanggan(Alimudin, Falani, Setiawan, \& Arifin, 2017). Perspektif pelanggan ini menentukan bagaimana perspektif proses bisnis internal dapat tercapai yang di dalamnya terdapat indikator-indikator pelayanan yang telah memiliki standar, produk yang memuaskan konsumen dan layanan retur pembelian(Alimudin, A., \& Yoga, 2015). Sedangkan perspektif pertumbuhan dan pembelajaran menitik beratkan kepada infrastruktur perusahaan di mana karyawan sebagai aset perusahaan yang berperan sebagai ujung tombak perusahaan dalam memberikan produk perusahaaan yang dapat berupa barang atau jasa. Jadi metode ini saling terkait antara yang satu dengan yang lainnya sehingga menciptakan suatu kondisi yang balanced antara finansial dengan aspekaspek yang mendukung tercapainya finansial perusahaan yang diharapkan (Narayanamma, 2017).

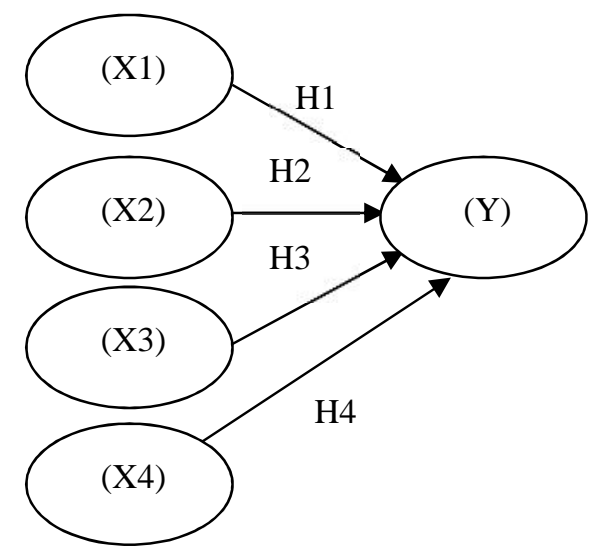

Gambar 1. Kerangka Pemikiran Teoritik

Penjelasan gambar 1 Kerangka Pemikiran Teoritik sebagai berikut :

\section{Pengaruh Perspektif Keuangan(X1) terhadap Kinerja UMKM (Y)}

Sim dan Koh (2001), melakukan perbandingan sistem pengukuran kinerja tradisional yang didasarkan pada indikator keuangan dengan Balanced Scorecard dan pengaruh dari kedua sistem pada kinerja perusahaan. Dan pada penelitian ini dikonfirmasi dampak positif Balanced Scorecard dan kinerja sistem pengukuran yang terkait dengan strategi dan tujuan. Demikian juga hasil penelitian Endang Kiswara (2005), yang menjelaskan bahwa pengukuran pada perspektif keuangan yang meliputi ROI, profit margin, dan operating ratio diperoleh hasil bahwa kinerja perusahaan dapat dikatakan cukup baik, meskipun terjadi penurunan dari tahun sebelumnya. Hasil penelitian tersebut juga sejalan dengan yang ditemukan oleh Mulyani, S. (2014) bahwa terdapat pengaruh 
yang positif dan signifikan antara ukuran usaha terhadap kualitas laporan keuangan UMKM. Berdasarkan hasil penelitian tersebut maka di ajukan hipotesis sebagai berikut:

H1: X1 (Perspektif Keuangan) berpengaruh positif terhadap Y (Kinerja UMKM). Pengaruh Perspektif Pelanggan(X2) terhadap Kinerja UMKM (Y)

Endang Kiswara (2005), didalam hasil penelitian menyatakan bahwa perspektif pelanggan mempengaruhi kinerja perusahaan. Demikian juga penelitian Sudiarta, I. P. L. E., Kirya, I. K., dan Cipta, W. (2014) yang menjelaskan bahwa faktor pemasaran yang berfokus kepada pelanggan merupakan salah satu faktor yang paling dominan mempengaruhi kinerja UMKM. Sehingga dapat disimpulkan bahwa perspektif pelanggan berpengaruh terhadap kinerja UMKM.

H2: X2 (Perspektif Pelanggan) berpengaruh positif terhadap Y (Kinerja UMKM).

Pengaruh Perspektif Proses Bisnis Internal(X3) terhadap Kinerja UMKM (Y) Junaidi (2002), melakukan analisis kontribusi penerapan Balanced Scorecard terhadap kinerja perusahaan, menghasilkan kesimpulan perspektif proses bisnis internal mempunyai kontribusi dan mempunyai hubungan yang cukup signifikan dan dapat menjadi proses umpan balik dengan terciptanya hubungan sebab akibat yang dapat memberikan kontribusi terhadap peningkatan kinerja perusahaan.

H3: X3 (Perspektif Proses Bisnis Internal) berpengaruh positif terhadap Y (Kinerja UMKM).

Pengaruh Perspektif Pembelajaran dan Pertumbuhan(X4) terhadap Kinerja UMKM (Y)

Tandiontong, M., dan Yoland, E. R (2011), menemukan pengaruh penerapan balanced scorecard terhadap sistem pengukuran kinerja yang memadai pada perusahaan Bio Tech Sarana, sudah termasuk kedalam kategori cukup baik artinya terdapat pengaruh yang signifikan antara penerapan balanced scorecard terhadap keefektifan sistem pengukuran kinerja. Demikian juga hasil penelitian Ardiana, I. D. K. R., Brahmayanti, I. A., dan Subaedi, S. (2010). Menemukan bahwa Kompetensi SDM UKM berpengaruh positif dan signifikan terhadap kinerja UKM di Surabaya. Sehingga dapat dirumuskan hipotesis sebagai berikut:

H4: X4 (Perspektif Pembelajaran dan Pertumbuhan) berpengaruh positif terhadap Y (Kinerja UMKM). 


\section{METODE PENELITIAN}

Berdasarkan masalah dan tujuan dari penelitian ini dilakukan maka pendekatan yang digunakan pada penelitian ini adalah deskriptif kuantitatif, data yang diperoleh dari sampel populasi penelitian dianalisis sesuai dengan metode statistik yang digunakan untuk menguji hipotesis, kemudian diinterprestasikan(Sugiyono, 2011). Populasi dalam penelitian ini adalah UMKM sektor perdagangan yang diteliti disini adalah usaha yang masuk dalam Kriteria Usaha Mikro, dimana menurut Keputusan Menteri Keuangan No.40/KMK.06/2003 tanggal 29 Januari 2003, yaitu usaha produktif milik keluarga atau perorangan Warga Negara Indonesia dan memiliki hasil penjualan paling banyak Rp.100.000.000,00 (seratus juta rupiah) per tahun.

Adapun karakteristik responden untuk penelitian ini yaitu:

a) Target responden adalah pelaku Usaha Mikro sektor perdagangan yang berdomisili di Surabaya.

b) Kriteria responden adalah :

a.pemilik atau penanggung jawab dalam usaha tersebut

b.usia responden 17-60 th

c.lama menjalankan usaha minimal 1 tahun

Sedangkan pada saat penelitian ini dilakukan 2017 belum diketahui dengan tepat, maka besar sampel yang dapat ditentukan didasarkan pada persyaratan penelitian analisis regresi berganda dimana ukuran sampel sebaiknya 10x lebih besar dari jumlah variabel dalam penelitian (Uma, S., 2006) dan menurut Widayat, A. (2002) besarnya jumlah sampel minimum yang diambil dalam penelitian yang bersifat deskriptif adalah sebesar 100 responden. Variabel dalam penelitian ini ada lima variabel, maka sample penelitian ditetapkan sebesar 100 responden dengan menggunakan teknik purposive random sampling. Dalam rangka penyusunan kuesioner, masing-masing variabel terdapat kriteria-kriteria yang dapat dijadikan pedoman. Tabel berikut memberikan rangkuman atas kriteria-kriteria untuk masing-masing variabel.

Perspektif Keuangan (X1)

1. Kemampuan untuk meningkatkan penjualan produk

2. Kemampuan untuk Meningkatkan laba perusahaan

3. Usaha untuk melakukan efisiensi biaya 
Perspektif Pelanggan (X2)

1. Kemampuan untuk mendapatkan kepercayaan pelanggan

2. Hubungan yang baik dengan pelanggan baik internal maupun eksternal

3. Kemampuan mempertahankan pelanggan lama

4. Pelayanan kepada pelanggan

Perspektif Proses Bisnis Internal (X3)

1. Kemampuan dalam pengelolaan stock barang yang dijual

2. Kemampuan menjaga kualitas barang

3. Usaha untuk menjaga kontinuitas penjualan

Perspektif Pembelajaran dan Pertumbuhan (X4)

1. Kemauan untuk tetap belajar

2. Keikutsertaan dalam pengembangan diri

3. Kompetensi untuk menjalankan usaha

Kinerja Perusahaan (Y)

1. Peningkatan pendapatan

2. Peningkatan pertumbuhan keuntungan

3. Peningkatan pertumbuhan pelanggan

Instrumen dalam penelitian ini menggunakan skala Likert untuk mengukur setiap pernyataan yang ada pada kuesioner perspektif keuangan, pelanggan, proses bisnis internal, pembelajaran dan pertumbuhan serta kinerja perusahaan. Setiap jawaban dihubungkan dengan bentuk pernyataan atau dukungan sikap yang diungkapkan dengan kata-kata sebagai berikut:

Sangat Setuju (SS ) $\quad=5$

Setuju $(\mathrm{S}) \quad=4$

Netral $(\mathrm{N}) \quad=3$

Tidak Setuju (TS) $\quad=2$

Sangat Tidak Setuju (STS) $=1$

Selain daripada itu dalam penelitian ini juga menggunakan skala rating untuk mengukur urutan (prioritas) terpenting menurut responden terhadap peningkatan kinerja perusahaan.

Teknik analisis data yang digunakan dalam penelitian ini adalah Dalam menganalisis data digunakan uji statistik dan dibagi empat tahapan, yaitu tahap persiapan, 
analisis deskriptif, pengujian terhadap kualitas data dan pengujian hipotesis. Dalam melakukan uji statistika digunakan program aplikasi SPSS versi 23. Analisis data dalam pengujian hipotesis menggunakan analisis regresi. Analisis regresi adalah suatu analisis yang digunakan untuk mengetahui atau memprediksi suatu variabel yang dipengaruhi oleh satu atau lebih variabel lainnya. Untuk mengetahui apakah ada hubungan regresi yang linear diantara variabel bebas dengan variabel terikatnya maka perlu dilakukan suatu uji. Uji yang digunakan disini dengan menggunakan uji Anova terhadap kuadrat deviasi dari model regresi tersebut. Untuk menguji relasi antar variabel-variabel dalam model regresi berganda digunakan nilai $\mathrm{F}$ ratio dari tabel anova dibandingkan dengan nilai ambang F dengan nilai $\square$ tertentu.

\section{HASIL \& PEMBAHASAN}

Hasil uji validitas menggunakan korelasi product moment Pearson, diketahui bahwa semua item pertanyaan pada kuesioner mempunyai korelasi yang signifikan pada tingkat kesalahan sebesar 0.05 , dimana hasil perhitungan menunjukan semua instrument pertanyaan memiliki nilai $>$ dari $\mathrm{r}$ tabel(0.1684) sehingga dapat dikatakan semua item pertanyaan adalah valid dan Semua variabel sudah dapat dikatakan reliabel karena telah memenuhi batasan nilai reliabilitas (alpha) $>0,70$ sehingga dapat diolah lebih lanjut.

Hasil dari output spss standard deviasi dan jumlah responden dari masing-masing responden yang secara lengkap tersaji pada tabel 1 .

Tabel 1. Statistik Deskriptif masing-masing Variabel.

\begin{tabular}{|l|c|c|c|}
\hline \multicolumn{1}{|c|}{ Variabel } & Mean & Standar Deviasi & N \\
\hline Perspektif Keuangan & 3,7345 & 0,5350 & 135 \\
\hline Perspektif Pelanggan & 3,7485 & 0,4342 & 135 \\
\hline Perspektif Proses Bisnis Internal & 3,8376 & 0,5027 & 135 \\
\hline Perspektif Pembelajaran dan & 3,7278 & 0,4815 & 135 \\
\hline Kinerja Perusahaan & 3,7792 & 0,3411 & 135 \\
\hline
\end{tabular}

Terlihat pada tabel 1 bahwa variabel bebas yaitu perspektif keuangan paling besar standard deviasinya yang berarti tingginya keragaman jawaban responden dibandingkan dengan variabel pelanggan, proses bisnis internal, pembelajaran dan pertumbuhan dan variabel terikat kinerja perusahaan. Hal ini berarti dalam perspektif keuangan lebih beragam dibandingkan dengan perspektif lainnya dalam rangka meningkatkan kinerja perusahaan. 
Tabel 2.Urutan(Prioritas)Perspektif Terpenting Menurut Responden

\begin{tabular}{|c|c|c|c|c|c|c|c|c|}
\hline \multirow{2}{*}{ Perspektif } & \multicolumn{2}{|c|}{ Prioritas 1} & \multicolumn{2}{|c|}{ Prioritas 2} & \multicolumn{2}{|c|}{ Prioritas 3} & \multicolumn{2}{|c|}{ Prioritas 4} \\
\hline & Freq & $\%$ & Freq & $\%$ & Freq & $\%$ & Freq & $\%$ \\
\hline Keuangan & 110 & $63 \%$ & 68 & $38.86 \%$ & 30 & $17.14 \%$ & 30 & $17.14 \%$ \\
\hline Pelanggan & 40 & $23 \%$ & 92 & $52.57 \%$ & 28 & $16.00 \%$ & 41 & $23.43 \%$ \\
\hline Proses Bisnis Internal & 19 & $11 \%$ & 6 & $3.43 \%$ & 87 & $49.71 \%$ & 34 & $19.43 \%$ \\
\hline $\begin{array}{l}\text { Pembelajaran dan } \\
\text { Pertumbuhan }\end{array}$ & 6 & $3 \%$ & 9 & $5.14 \%$ & 30 & $17.14 \%$ & 70 & $40.00 \%$ \\
\hline Total & 175 & $100 \%$ & 175 & $100 \%$ & 175 & $100 \%$ & 175 & $100 \%$ \\
\hline
\end{tabular}

Dari tabel 2 dapat dijelaskan pemilihan urutan (prioritas) perspektif terpenting menurut responden terhadap kinerja perusahaan (Tabel 1), prioritas pertama ditempati perpektif pembelajaran dan pertumbuhan sebesar $62.89 \%$, prioritas kedua ditempati perspektif proses bisnis internal sebesar $52.58 \%$, prioritas ketiga ditempati perspektif pelanggan sebesar $50.52 \% \%$ dan prioritas keempat ditempati perspektif keuangan sebesar $40.21 \%$.

Pengujian Hipotesis

Hipotesis pertama:

H0 : Tidak terdapat kontribusi penerapan perspektif Financial terhadap kinerja perusahaan

H1 : Terdapat kontribusi penerapan perspektif Financial terhadap kinerja perusahaan Pengujian statistik :

$\mathrm{H} 0: \beta_{1}=0$

$\mathrm{H} 1: \beta_{1} \neq 0$

Tabel 3 menunjukan seberapa banyak kontribusi dari model regresi untuk dapat menjelaskan variabel terikat, dalam hal ini dengan melihat koefisien multi korelasinya. Angka R sebesar 0,715 menunjukkan bahwa korelasi/hubungan antara Variabel terikat yaitu kinerja perusahaan dengan variabel bebas Perspektif Keuangan adalah kuat karena berada diatas angka 0,5 (Sugiyono, 2011). Angka Adjusted R Square atau Koefisien Determinasi adalah 0,505. Hal ini berarti $50.5 \%$ variasi dari kinerja perusahaan bisa dijelaskan oleh variabel bebas perspektif keuangan. Dari uji Anova atau F test, didapat F hitung adalah 99,115 dengan tingkat signifikansi 0,000. Hal ini menjelaskan bahwa Perspektif Keuangan mempunyai kontribusi terhadap kinerja perusahaan.

Tabel 3. Pengujian Hipotesis pertama dengan Analisis Regresi 
Model Summary

\begin{tabular}{|l|r|r|r|rr|}
\hline Model & $\mathrm{R}$ & $\mathrm{R}$ Square & \multicolumn{1}{|c|}{$\begin{array}{c}\text { Adjusted } \mathrm{R} \\
\text { Square }\end{array}$} & Std. Error of the Estimate \\
\hline 1 & $.715^{\mathrm{a}}$ & .511 & .505 & .240 \\
\hline
\end{tabular}

a. Predictors: (Constant), Perspektif Keuangan

ANOVA $^{\mathrm{a}}$

\begin{tabular}{|c|c|c|c|c|c|c|}
\hline & Sum of Squares & df & Mean Square & $\mathrm{F}$ & Sig. \\
\hline \multirow{3}{*}{$\frac{\text { Model }}{1}$} & Regression & 5.708 & 1 & 5.708 & 99.115 & $.000^{\mathrm{b}}$ \\
\hline & Residual & 5.471 & 95 & .058 & & \\
\hline & Total & 11.180 & 96 & & & \\
\hline
\end{tabular}

a. Dependent Variable: Kinerja Perusahaan

b. Predictors: (Constant), Perspektif Keuangan

\section{Hipotesis Kedua:}

H0 : Tidak terdapat kontribusi penerapan perspektif Customer terhadap kinerja perusahaan

H1 : Terdapat kontribusi penerapan perspektif Customer terhadap kinerja perusahaan Pengujian statistik :

$\mathrm{H} 0: \beta_{1}=0$

$\mathrm{H} 1: \beta_{1} \neq 0$

Tabel 4. Pengujian Hipotesis kedua dengan Analisis Regresi.

Model Summary

\begin{tabular}{|l|r|r|r|r|}
\hline Model & R & R Square & Adjusted R Square & Std. Error of the Estimate \\
\hline 1 & $.755^{\mathrm{a}}$ & .570 & .565 & .225 \\
\hline
\end{tabular}

a. Predictors: (Constant), Perspektif Pelanggan

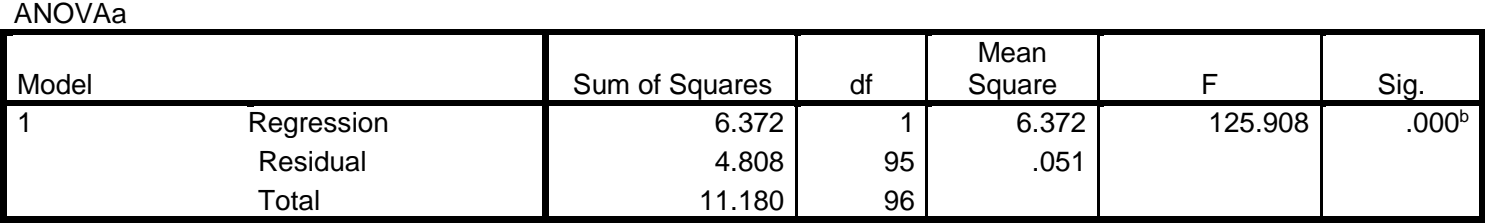

a. Dependent Variable: Kinerja Perusahaan

b. Predictors: (Constant), Perspektif Pelanggan

Pada tabel 4 dapat dijelaskan angka $\mathrm{R}$ sebesar 0,755 menunjukkan bahwa korelasi/hubungan antara Variabel terikat yaitu kinerja perusahaan dengan variabel bebas Perspektif Pelanggan adalah kuat karena berada diatas angka 0,5 (Sugiyono, 2011). Angka Adjusted R Square atau Koefisien Determinasi adalah 0,565. Hal ini berarti 56.5 $\%$ variasi dari kinerja perusahaan bisa dijelaskan oleh variabel bebas perspektif pelanggan. Berdasarkan nilai probabilitas dari uji Anova atau F test, didapat F hitung adalah 125.908 dengan tingkat signifikansi 0,000. Hal ini menjelaskan bahwa Perspektif Pelanggan mempunyai kontribusi terhadap kinerja perusahaan.

Tabel 5. Pengujian Hipotesis ketiga dengan Analisis Regresi. 


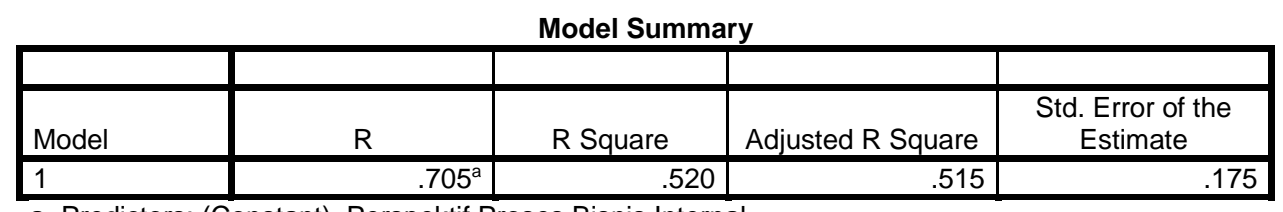

a. Predictors: (Constant), Perspektif Proses Bisnis Internal

\section{ANOVA $^{a}$}

\begin{tabular}{|c|c|c|c|c|c|c|}
\hline \multicolumn{2}{|c|}{ Model } & Sum of Squares & df & Mean Square & $\mathrm{F}$ & Sig. \\
\hline 1 & Regression & 6.150 & 1 & 6.250 & 120.902 & $.000^{\mathrm{b}}$ \\
\hline & Residual & 4.230 & 95 & .045 & & \\
\hline & Total & 10.380 & 96 & & & \\
\hline
\end{tabular}

a. Dependent Variable: Kinerja Perusahaan

b. Predictors: (Constant), Perspektif Proses Bisnis Internal

Pada tabel 5 dapat dijelaskan bahwa angka $\mathrm{R}$ sebesar 0,705 menunjukkan korelasi/hubungan antara Variabel terikat yaitu kinerja perusahaan dengan variabel bebas Perspektif Proses Bisnis Internal adalah kuat karena berada diatas angka 0,5 (Sugiyono, 2011)

Angka Adjusted R Square atau Koefisien Determinasi adalah 0,515. Hal ini berarti $51.5 \%$ variasi dari kinerja perusahaan bisa dijelaskan oleh variabel bebas perspektif proses bisnis internal. Dari uji Anova atau F test, didapat F hitung adalah 120.902 dengan tingkat signifikansi 0,000. maka dapat dikatakan bahwa model ini layak digunakan untuk regresi. Hal ini menjelaskan bahwa Perspektif Proses Bisnis Internal mempunyai kontribusi terhadap kinerja perusahaan.

\section{Hipotesis Keempat:}

H0 : Tidak terdapat kontribusi penerapan perspektif Learning And Growth terhadap kinerja perusahaan

H1 : Terdapat kontribusi penerapan perspektif Learning And Growth terhadap kinerja perusahaan

Pengujian statistik :

$\mathrm{H} 0: \beta_{1}=0$

$\mathrm{H} 1: \beta_{1} \neq 0$

Tabel 6. Pengujian Hipotesis keempat dengan Analisis Regresi.

\begin{tabular}{|c|c|c|c|c|}
\hline \multicolumn{5}{|c|}{ Model Summary } \\
\hline Model & $\mathrm{R}$ & R Square & $\begin{array}{l}\text { Adjusted R } \\
\text { Square }\end{array}$ & $\begin{array}{l}\text { Std. Error of the } \\
\text { Estimate }\end{array}$ \\
\hline 1 & $.854^{\mathrm{a}}$ & .730 & .727 & .178 \\
\hline
\end{tabular}

a. Predictors: (Constant), Perspektif Pembelajaran dan Pertumbuhan 
ANOVA $^{\mathrm{a}}$

\begin{tabular}{|ll|r|r|r|r|r|}
\hline Model & Sum of Squares & df & Mean Square & F & Sig. \\
\hline 1 & Regression & 8.163 & 1 & 8.163 & 257.059 & $.000^{\mathrm{b}}$ \\
& Residual & 3.017 & 95 & .032 & & \\
& Total & 11.180 & 96 & & & \\
\hline
\end{tabular}

a. Dependent Variable: Kinerja Perusahaan

b. Predictors: (Constant), Perspektif Pembelajaran dan Pertumbuhan

Pada tabel 6 dapat dijelaskan angka $\mathrm{R}$ sebesar 0,854 menunjukkan bahwa korelasi/hubungan antara Variabel terikat yaitu kinerja perusahaan dengan variabel bebas Perspektif Pembelajaran dan Pertumbuhan adalah kuat karena berada diatas angka 0,5 (Sugiyono, 2011)

Angka Adjusted R Square atau Koefisien Determinasi adalah 0,727. Hal ini berarti $72.7 \%$ variasi dari kinerja perusahaan bisa dijelaskan oleh variabel bebas perspektif pembelajaran dan pertumbuhan.Dari uji Anova atau F test, didapat F hitung adalah 257.059 dengan tingkat signifikansi 0,000. Hal ini menjelaskan bahwa Perspektif Pembelajaran dan Pertumbuhan mempunyai kontribusi terhadap kinerja perusahaan.

Hipotesis Kelima:

H0 : Tidak terdapat kontribusi penerapan perspektif keempat perspektif Balanced Scorecard terhadap kinerja perusahaan

H1 : Terdapat kontribusi penerapan perspektif keempat perspektif Balanced Scorecard terhadap kinerja perusahaan.

Pengujian statistik :

$\mathrm{H}_{0}: \beta_{1}=\beta_{2}=\beta_{3}=\beta_{4}=0$

$\mathrm{H}_{1}: \beta_{1}, \beta_{2}, \beta_{3}, \beta_{4} \neq 0$

Tabel 6. Pengujian Hipotesis kelima dengan Analisis Regres

Model Summary

\begin{tabular}{l|c|c|c|c|}
\hline Model & $\mathrm{R}$ & $\mathrm{R}$ Square & $\begin{array}{c}\text { Adjusted R } \\
\text { Square }\end{array}$ & Std. Error of the Estimate \\
\hline 1 & $.976^{\mathrm{a}}$ & .952 & .950 & .076 \\
\hline a. & $\begin{array}{l}\text { Predictors: (Constant), Perspektif Pembelajaran dan Pertumbuhan, Perspektif Proses Bisnis Internal, Perspektif } \\
\text { belanggan, Perspektif Keuangan }\end{array}$ \\
b. $\quad$ Dependent Variable: Kinerja Perusahaan
\end{tabular}

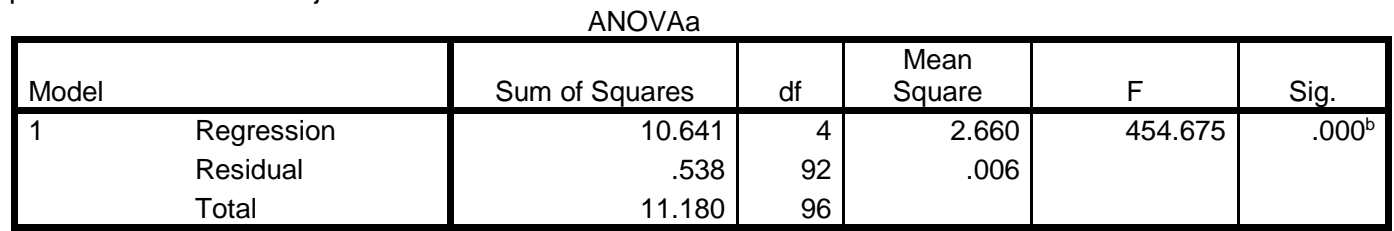

a. Dependent Variable: Kinerja Perusahaan

b. Predictors: (Constant), Perspektif Pembelajaran dan Pertumbuhan, Perspektif Proses Bisnis Internal, Perspektif Pelanggan, Perspektif Keuangan 
Pada tabel 6 menunjukan angka $\mathrm{R}$ sebesar 0,976 menunjukkan bahwa korelasi/hubungan antara Variabel terikat yaitu kinerja perusahaan dengan 4 variabel bebas adalah kuat karena berada diatas angka 0,5 (Sugiyono, 2011). Angka R Square atau Koefisien Determinasi adalah 0,952. Namun untuk jumlah variabel bebas lebih dari dua, lebih baik digunakan Adjusted R Square yaitu sebesar 0,950. Hal ini berarti $95 \%$ variasi dari kinerja perusahaan bisa dijelaskan oleh variasi dari keempat variabel bebas. Sedangkan sisanya $(100 \%-95 \%=5 \%)$ dijelaskan oleh sebab-sebab lain. Dari uji Anova atau $\mathrm{F}$ test, didapat $\mathrm{F}$ hitung adalah 454,675 dengan tingkat signifikansi 0,000. Hal ini menjelaskan bahwa Perspektif Keuangan, Pelanggan, Proses Bisnis, Pembelajaran dan Pertumbuhan mempunyai kontribusi terhadap kinerja perusahaan.

Pembahasan hasil penelitian mengenai kontribusi penerapan masing-masing perspektif Financial, Customer, Internal Business Process dan Learning and Growth dan Balanced Scorecard secara keseluruhan terhadap peningkatan kinerja UMKM sektor perdagangan di Surabaya :

a) UMKM membutuhkan adanya karyawan yang kompeten dari adanya pelatihan, perhatian dan penghargaan serta dukungan sistem informasi yang baik (Perspektif Pembelajaran dan Pertumbuhan).

b) Dari perspektif diatas diharapkan dapat memberikan komitmen dan produktivitas dalam meningkatkan kualitas proses layanan kepada pelanggan melalui inovasi produk/jasa yang ditawarkan serta usulan penyederhanaan proses bisnis yang diperlukan dalam rangka melakukan efisiensi biaya dan penggunaan asset secara optimal (Perspektif Proses Bisnis Internal).

c) Kualitas proses layanan diatas diharapkan dapat menarik pelanggan dalam rangka meningkatkan kepercayaan dan kepuasan pelanggan (Perspektif Pelanggan).

d) Dengan tercapainya tujuan perspektif pelanggan maka dapat memberikan dampak terhadap peningkatan pendapatan perusahaan, sedangkan dengan adanya efisiensi biaya dapat meningkatkan keuntungan perusahaan (Perspektif Keuangan).

Sedangkan dari hasil analisis regresi dapat Adjusted R Square sebesar $95 \%$ dari empat variabel perspektif Balanced Scorecard dapat menjelaskan kinerja perusahaan. Hal ini menunjukkan pula bahwa empat variabel tersebut berpengaruh terhadap kinerja perusahaan. Faktor lain yaitu $(100 \%-95 \%=5 \%)$ dapat dijelaskan oleh faktor-faktor 
lain yang mungkin berpengaruh misalnya underwriter performance, kebijakan pemerintah (contohnya kenaikan pajak yang dapat mengakibatkan penurunan permintaan), peraturan pemerintah (contohnya larangan memproduksi suatu produk/jasa), faktor lingkungan sekitar serta faktor-faktor random lainnya seperti bencana alam, kerusuhan dan lain-lain

\section{SIMPULAN \& SARAN}

\section{Kesimpulan}

1. Perspektif Financial/ Keuangan memiliki kontribusi dalam peningkatan kinerja UMKM sebesar $50.5 \%$

2. Perspektif Customer/ Pelanggan memiliki kontribusi dalam peningkatan kinerja UMKM sebesar $56.5 \%$

3. Perspektif Internal Business Process/ Proses Bisnis Internal memiliki kontribusi dalam peningkatan kinerja UMKM sebesar $51.5 \%$

4. Perspektif Learning and Growth/ Pembelajaran dan pertumbuhan Learning and Growth/ Pembelajaran dan pertumbuhan memiliki kontribusi dalam peningkatan kinerja UMKM sebesar $72.7 \%$.

5. Empat perspektif Balanced Scorecard secara signifikan memiliki kontribusi dalam peningkatan kinerja UMKM sebesar $95.5 \%$. Faktor lain yaitu $(100 \%-95 \%=5 \%)$ dapat dijelaskan oleh faktor-faktor lain yang mungkin berpengaruh misalnya underwriter performance, kebijakan pemerintah (contohnya kenaikan pajak yang dapat mengakibatkan penurunan permintaan), peraturan pemerintah (contohnya larangan memproduksi suatu produk/jasa), faktor lingkungan sekitar serta faktorfaktor random lainnya seperti bencana alam, kerusuhan dan lain-lain..

\section{Saran}

1. Perlu dilakukan pengkajian lebih dalam kembali terhadap hasil-hasil yang telah dicapai serta upaya mengevaluasi kembali program tindakan yang telah dilakukan setelah periode implementasi dilaksanakan pada periode tertentu agar tujuan dari masing-masing perspektif dapat tercapai secara optimal (contohnya mengevaluasi kemajuan program dan mengusulkan perubahan strategi yang dipandang perlu sebagai umpan balik kepada pihak UMKM). 
2. Usaha sosialiasi sistem pengukuran model BSC masih perlu terus dilakukan secara berkesinambungan sehingga tercipta proses permbelajaran pada semua tingkat organisasi yang ada UMKM agar perusahaan memperoleh dukungan \& komitmen dari karyawan secara penuh.

3. Implementasi strategi pada perusahaan di era informasi sekarang ini tidak dapat sederhana dan semudah seperti masa lalu. Oleh karena itu umpan balik sangat penting dan perlu dikelola secara baik, sehingga memungkinkan adanya kesempatan untuk secara periodik melakukan evaluasi, apakah strategi yang dilaksanakan masih sesuai dengan perkembangan terakhir dan mencari ide-ide di seluruh jajaran perusahaan mengenai arah dan peluang strategi yang baru.

4. Perlu dilakukan cascading atau penurunan sasaran strategis dan indikator kinerja utama ke level bawahannya hingga level individu agar perbaikan kinerja perusahaan dapat dilakukan secara menyeluruh.

5. Perlu dibuat suatu sistem informasi atau aplikasi penilaian kinerja yang dapat diakses dan digunakan dengan mudah oleh UMKM, sehingga semua pihak yang berkepentingan dapat memonitor kinerja UMKM dengan benar dan cepat.

\section{DAFTAR PUSTAKA}

Alimudin, A., \& Yoga, H. (2015). STRATEGI MENINGKATKAN LOYALITAS PELANGGAN PADA USAHA KECIL PRODUK MAKANAN RINGAN DI SURABAYA. Sustainable Competitive Advantage (SCA), 5(1).

Alimudin, A., Falani, A. Z., Setiawan, E., \& Arifin, B. (2017). The Use of Fuzzy Logic in Developing Competitiveness Strategy Toward Small and Medium Enterprises ( Grocery ), 23(12), 11867-11873. https://doi.org/10.1166/asl.2017.10534

Ardiana, I. D. K. R., Brahmayanti, I. A., \& Subaedi, S. (2010). Kompetensi SDM UKM dan pengaruhnya terhadap kinerja UKM di Surabaya. Jurnal manajemen dan Kewirausahaan, 12(1), pp-42

Bank Indonesia. (2016). Profil Bisnis Usaha Mikro, Kecil dan Menengah (UMKM). Jakarta, Indonesia: Lembaga Pengembangan Perbankan Indonesia. Retrieved from www.bi.go.id/id/umkm/penelitian/nasional/kajian/.../Profil Bisnis UMKM.pdf

Hadiyati, E. (2010). Kajian Pendekatan Pemasaran Kewirausahaan dan Kinerja Penjualan Usaha Kecil. Jurnal Manajemen dan Kewirausahaan, 11(2), pp-183.

Junaidi. 2002. Kontribusi Penerapan Balanced Scorecard Terhadap Peningkatan Kinerja Perusahaan, Jakarta, Juli. 2002

Kaplan, R. S., \& Norton, D. P. (1996). The Balanced Scorecard Translating Strategy In Action (Kaplan \& Norton, 1996, Harvard Business School Press).pdf. Proceedings of the IEEE. https://doi.org/10.1109/JPROC.1997.628729

Kiswara, Endang, 2005, Analisis Balanced Scorecard Sebagai Alat Pengukur Kinerja Perusahaan. 
Mulyani, S. (2014). Faktor-faktor yang Mempengaruhi Kualitas Laporan Keuangan pada UMKM di Kabupaten Kudus. Jurnal Dinamika Ekonomi \& Bisnis, 11(2).

Narayanamma, P. L. (2017). A Study On Impact Of Balanced Scorecard Implementation On Job Satisfaction Of Employees In Selected Public And Private Sector. Shanlax International Journal of Arts, Science and Humanities, 4(3), 44-52. Retrieved from www.shanlaxjournals.in/pdf/SPL/loyola_spl.pdf

Phong Tuan, Nham dan Yoshi, T. (2010). Organizational capabilities, competitive advantage and performance in supporting industries in vietnam. Asian academy of management journal, Vol. 15(1), 1-21.

Sasono, A. D., Alimudin, A., Kamisutara, M., \& Inayati, I. (2015). Development of accounting information system (SIA-UMKM) with waterfall approach to standardize UMKM financial report based on standard of accounting financial entity without public accountability (SAK-ETAP). J. Basic. Appl. Sci. Res.

Sim, K. L., dan Koh, H. C. (2001). Balanced Scorecard: A Rising Trend in Strategic Performance, Measurement. In: Measuring Business Excellence, Vol. 5(2).

Sudiarta, I. P. L. E., Kirya, I. K., dan Cipta, W. (2014). Analisis Faktor-Faktor Yang Mempengaruhi Kinerja Usaha Mikro Kecil Dan Menengah (Umkm) Di Kabupaten Bangli. Jurnal Jurusan Manajemen, 2(1).

Sugiyono. (2011). Metode Penelitian Kuantitatif, kualitatif dan R \& D. Bandung: Alfabeta, 90. https://doi.org/10.1017/CBO9781107415324.004

Tandiontong, M., \& Yoland, E. R. (2011). Penerapan Balanced Scorecard Sebagai Alat Pengukuran Kinerja Yang Memadai (Sebuah Studi Pada Perusahaan Bio Tech Sarana di Bandung). Jurnal Ilmiah Akuntansi.

Uma, S. (2006). Metodologi penelitian untuk bisnis. Jakarta: Salemba Empat.

Widayat, A. (2002). Riset Bisnis. Yogyakarta: Graha Ilmu. 